\title{
PENGARUH PERSEPSI GURU TENTANG KEPEMIMPINAN KEPALA SEKOLAH TERHADAP KINERJA GURU DI SMA LABORATORIUM UNDIKSHA SINGARAJA TAHUN PELAJARAN 2017
}

\author{
Ni Putu Mega Lusiana \\ Jurusan Pendidikan Ekonomi \\ Universitas Pendidikan Ganesha \\ Singaraja, Indonesia. \\ e-mail:megalusiana18@gmail.com
}

\begin{abstract}
Abstrak
Penelitian ini bertujuan mengetahui persepsi guru tentang kepemimpinan kepala sekolah, kinerja guru di SMA Laboratorium Undiksha Singaraja, pengaruh persepsi guru tentang kepemimpinan kepala sekolah terhadap kinerja guru di SMA Laboratorium Undiksha Singaraja. Penelitian ini menggunakan rancangan kausalitas. Populasi dalam penelitian ini adalah 38 guru di SMA Laboratorium Undiksha Singaraja dan sampel yang digunakan adalah total dari populasi yang ada. Data dikumpulkan dengan menggunakan kuisioner dan dokumentasi, serta dianalisis dengan analisis deskriptif, analisis kuantitatif dan uji t dengan program SPSS versi 16.0 for windows. Hasil penelitian ini menunjukkan bahwa persepsi guru tentang kepemimpinan kepala sekolah berada pada kategori baik yaitu pada rata-rata skor 25,777 , kinerja guru tergolong dalam kategori sangat baik yaitu pada rata-rata skor 51,76 persepsi guru tentang kepemimpinan a kepala sekolah terhadap kinerja guru tidak berpengaruh secara signifikan ditunjukkan $p$-value $=0,092>\alpha=0.05$.
\end{abstract}

Kata kunci: kepemimpinan, kinerja, persepsi

\section{Abstract}

This study aims to know the effect of teacher's perceptions on principal's leadership the teacher's performance at the SMA Laboratorium Undiksha Singaraja, the effect of teacher's perceptions of the principal's leadership style on teacher performance at SMA Laboratorium Undiksha Singaraja. This research uses causality design. The population of this study is 38 teachers at SMA Laboratorium Undiksha Singaraja and the sample is used the total of the existing population. Data were collected by using questionnaire and documentation, and then they were analyzed by descriptive analysis, quantitative analysis and t test by using SPSS program version 16.0 for windows. The results of this study indicate that teacher's perceptions of the principal's leadership are in the good category, it is in the average score of 25,777, the teacher's performance is categorized as excellent in the average score of 51,76 teacher's perceptions of the principal's leadership on teacher performance were not significantly influenced which indicate by $p$-value $=0.092>\alpha=0.05$.

Keywords: leadership, perceptions, teacher's performance

\section{PENDAHULUAN}

Pendidikan yang bermutu merupakan syarat untuk mewujudkan kehidupan bangsa yang maju, modern dan sejahtera di masa depan. Menurut UU RI No 20 tahun 2013 pendidikan adalah usaha sadar dan terencana untuk mewujudkan suasana belajar dan proses pembelajaran agar peserta didik secara aktif mengembangkan potensi dirinya untuk memiliki kekuatan spiritual 
keagamaan, pengendalian diri, kepribadian, kecerdasan dan akhlak mulia, serta keterampilan yang diperlukan dirinya, masyarakat, bangsa dan negara. Banyak negara didunia ini yang tidak memiliki sumber daya alam melimpah namun dapat mewujudkan kemakmuran dan kesejahtraan rakyatnya. Hal tersebut terjadi karena kualitas pendidikan yang mereka laksanakan menghasilkan sumber daya manusia yang berkualitas. Untuk menyelenggarakan sumber daya manusia yang berkualitas, salah satu faktor yang harus dipenuhi adalah pendidik yang berperan aktif serta yang terdiri atas guru dan kepala sekolah.

Dari sudut pandang perilaku organisasi sekolah terdiri dari beberapa manusia dalam rangka mencapai visi dan misi, sehingga memerlukan tingkat koordinasi yang tinggi. Faktor sumber daya manusia merupakan faktor yang dapat menggerakkan tercapainya tujuan organisasi. Melihat betapa pentingnya peranan manusia dalam organisasi, maka kepala sekolah sebagai penentu kebijakan harus memberi perhatian yang lebih terhadap lingkungan sekolah dan orang-orang yang berada didalamnya. Kinerja guru banyak disangkutpautkan dengan rendahnya mutu pendidikan. Guru sebagai makhluk sosial memerlukan kebutuhan yang lain untuk dapat bekerja dengan baik. Untuk dapat berpikir serta bekerja secara maksimal dalam kerjanya, guru sangat dipengaruhi oleh lingkungan kerja dimana mereka bekerja serta mempunyai pemimpin yang profesional. Sekolah merupakan salah satu lembaga pendidikan diharapkan mampu meningkatkan kualitas sumber daya manusia. Untuk mencapai tujuan tersebut sekolah memerlukan pengelolaan terpadu baik oleh guru sebagai pelaksana kegiatan belajar mengajar dikelas maupun oleh kepala sekolah sebagai manajerial kegiatan di sekolah secara umum.

Manajemen yang baik oleh kepala sekolah melahirkan pencapaian tujuan sekolah dengan efektif dan efisien, serta pencapaian tujuan individu yang ada di lingkungan sekolah. Dalam hal ini, kepala sekolah memiliki peran penting dalam memimpin sekolah agar tujuan sekolah dapat tercapai dengan maksimal.Tugas para guru sebagai pendidik apabila tidak dilaksanakan dalam suatu sistem kerja yang kondusif akan mengakibatkan banyak guru yang kehilangan semangat kerja dalam menjalankan tugasnya. Menurunnya semangat inilah yang merupakan masalah yang harus dihindari. Oleh karena itu, tugas mendidik dari seorang guru ini pada dasarnya hanya dapat dilaksanakan oleh guru yang memiliki kinerja yang tinggi. Selain itu guru mempunyai tugas untuk mendidik dan melatih. Mendidik berarti meneruskan dan mengembangkan nilai-nilai hidup, mengajarkan berarti meneruskan dan mengembangkan ilmu pengetahuan, melatih berarti mengembangkan keterampilan-keterampilan pada siswa. Kinerja guru yang baik sangat diharapkan kepala sekolah dalam upaya mencapai tujuan sekolah karena kinerja guru merupakan unjuk kerja seseorang yang dihubungkan dengan tugas-tugas rutin yang dikerjakannya. Terciptanya kualitas kinerja guru yang profesional di sekolah membutuhkan dukungan peran kepala sekolah yang kompeten sebagai leader dan manager (Wahyudi, 2009). Disatu sisi, kepala sekolah berperan sebagai pemimpin yang memiliki visi kedepan yang jelas dan dapat diwujudkan serta mampu mendorong proses transparasi di sekolah. Kepala sekolah berperan sebagai manajer, yang memiliki kemampuan dalam kepemimpinan, perencanaan, dan pandangan yang luas tentang sekolah dan pendidikan. Kepala sekolah sebagai pemimpin harus bisa menjadi contoh serta mampu mengayomi bawahannya dan mampu mengendalikan fungsifungsi kepemimpinannya dengan baik dan bijaksana dalam organisasi sekolah. Kepemimpinan kepala sekolah yang efektif akan mempengaruhi partisipasi bawahan untuk melakukan apa yang menjadi tanggung jawabnya dengan perasaan puas dan dapat 
bekerja sesuai dengan konteknya, yaitu mampu memberikan visi, menciptakan gambaran besar menetapkan tujuan yang jelas dan disetujui bersama, memonitor dan menganalisis prestasi serta mampu mengembangkan prestasi para pengikutnya, yaitu dengan memberikan umpan balik. Kepemimpinan sebagai suatu kemampuan untuk menginspirasi kepercayaan dan dukungan kepada orang-orang yang dibutuhkan dalam rangka mencapai tujuan-tujuan dari lembaga. Kepemimpinan merupakan salah satu faktor yang mempengaruhi kerja karyawan atau guru. Penerapan kepemimpinan yang sesuai dengan karakteristik bawahan akan dapat membentuk suasana kerja yang baik dan meningkatkan motivasi kerja bawahan sehingga bawahan akan dapat menunjukkan kinerja terbaiknya (Permata, 2012).

Kepemimpinan yang digunakan kepala sekolah dalam berhadapan dengan bawahan yaitu gaya yang berorientasi pada tugas dan gaya yang berorientasi pada karyawan atau guru.

Kepala sekolah adalah seorang tenaga fungsional guru yang diberi tugas memimpin suatu sekolah dimana diselenggarakan proses belajar mengajar, atau tempat dimana terjadi interaksi antara guru yang member pelajaran dan murid yang menerima pelajaran (Wahjosumidjo, 2010). Kepala sekolah berorientasi kepada tugas artinya mengarahkan, mengawasi secara ketat bawahannya untuk memastikan bahwa tugas yang dijalankan bawahan memuaskan. Kepala sekolah yang berorientasi kepada bawahan mencoba memotivasi dan bukan mengendalikan, mendorong bawahan untuk melaksanakan tugas dengan membiarkan mereka berpartisipasi dalam keputusan yang mempengaruhi mereka, membentuk hubungan persahabatan saling percaya dan saling menghormati antar anggota organisasi sekolah.

Mutu proses pendidikan di sekolah dipengaruhi oleh sinergisnya proses interaksi antara faktor-faktor dari peran kepala sekolah sebagai pemimpin dan manager sekolah, kompetensi kepala sekolah, lingkungan sekolah terhadap faktor kinerja guru, lemahnya manajemen atas faktor-faktor tersebut akan mempengaruhi pencapaian tingkat mutu pendidikan pada sekolah sehingga kinerja menjadi kurang optimal. Kinerja individu adalah cara seorang pegawai melaksanakan pekerjaannya atau untuk kerjanya (Sedarmayanti, 2001). Melihat betapa pentingnya peranan kepala sekolah dalam sebuah sekolah dimana kepala sekolah harus dapat melakukan segala kewajibannya sehingga tercapainya tujuan sekolah, serta tujuan para individu yang ada di dalam lingkungan sekolah, harus memahami dan menguasai peranan organisasi dan hubungan kerja sama antara individu.

Dalam kaitannya dengan peranan kepemimpinan dalam meningkatkan kinerja guru dan pegawai, perlu dipahami bahwa setiap pemimpin bertanggung jawab mengarahkan apa yang baik bagi pegawainya dan dia sendiri harus berbuat baik. Pemimpin dalam hal ini kepala sekolah harus juga memberikan contoh kepada bawahan yaitu seperti sabar dan penuh pengertian. Sekolah Menengah Atas Laboratorium Undiksha Singaraja merupakan salah satu sekolah menengah atas yang berada di Singaraja. Sekolah ini merupakan salah satu sekolah yang Terakreditasi A di Singaraja yang beralamat di Jalan Jatayu No.10 Singaraja. SMA Laboratorium Undiksha Singaraja memiliki seorang pemimpin atau kepala sekolah yang sangat bertanggung jawab. SMA Laboratorium Undiksha Singaraja menjadi salah satu sekolah terkenal di Singaraja bahkan sampai daerah luar. Gedung yang megah sarana dan prasarana yang lengkap serta siswa yang berprestasi menjadikan sekolah ini menjadi sorotan bagi banyak orang. Menurut penelitian awal yang dilakukan peneliti melihat masih ada guru-guru yang terlambat mengajar dan datang kesekolah serta enggan memeriksa tugas siswa, hal ini 
menunjukkan bahwa kinerjanya belum maksimal. Selain itu, kepala sekolah di sekolah ini memang sudah melaksanakan tugasnya selaku pemimpin dengan baik akan tetapi diperlukan penelitian untuk mengetahui persepsi guru tentang kepemimpinan kepala sekolah dan pengaruhnya terhadap kinerja guru. Persepsi merupakan proses kognitif kompleks yang menghasilkan gambaran dunia yang unik, yang mungkin agak berbeda dari realita (Luthans, 2006).

Persepsi sebagai tindakan menyusun informasi dari organ-organ sensorik menjadi suatu keseluruhan yang bisa kita pahami. Organ-organ sensorik tersebut adalah indera penglihatan, pendengaran, peraba, perasa, dan penciuman. Informasi yang diperoleh dari indera-indera manusia ini kemudian membentuk persepsi yang dapat memberikan gambaran subjektif pada diri seseorang mengenai suatu kejadian ataupun pengalaman yang dialaminya. Walgito (2004) mengemukakan ada beberapa faktor yang dapat mempengaruhi persepsi sebagai berikut yaitu objek yang dipersepsikan, objek yang dipersepsi menimbulkan stimulus yang mengenai alat indera atau reseptor. Stimulus dapat datang dari luar individu yang mempersepsi tetapi juga dapat datang dari dalam individu yang bersangkutan yang langsung mengenai syaraf penerima yang bekerja sebagai reseptor, namun sebagian terbesar datang dari luar individu. Alat indera atau reseptor merupakan alat untuk menerima stimulus. Disamping itu juga harus ada syaraf sensoris sebagai alat untuk meneruskan stimulus yang diterima reseptor ke pusat susunan syaraf, yaitu otak sebagai pusat kesadaran dan sebagai alat untuk mengadakan respon yang diperlukan syaraf motoris, untuk menyadari atau untuk mengadakan persepsi diperlukan adanya perhatian.

Perhatian adalah merupakan

pemusatan atau konsentrasi dari seluruh aktivitas individu yang ditunjukkan kepada sesuatu atau sekumpulan objek tertentu. Kepemimpinan merupakan proses kegiatan seseorang yang memiliki seni atau kemampuan untuk mempengaruhi, mengkoordinasikan, menggerakkan individu-individu tanpa adanya paksaan agar dapat bekerja sama secara teratur dalam upaya mencapai tujuan bersama yang telah ditetapkan" (Wahyudi, 2012). Kepemimpinan pendidikan adalah pemimpin pada satu lembaga satuan pendidikan.Tanpa kehadiran kepemimpinan pendidikan ini, proses pendidikan termasuk pembelajaran tidak akan berjalan secara efektif.

Proses kepemimpinan dijalankan oleh seorang pemimpin. Pemimpin dalam menjalankan fungsifungsi kepemimpinan harus memiliki kecakapan khusus, seperti kewibawaan dan kekuasaan untuk menggerakkan orang lain dan bawahan, memiliki pengetahuan luas, dan bervisi jauh kedepan serta memenuhi syarat-syarat tertentu dan mampu mempengaruhi kegiatan-kegiatan anggota kelompok. Selain itu, pemimpin juga dituntut untuk dapat menciptakan hubungan personal dengan orang lain, berempati dengan kebutuhan orang lain, serta tidak memaksakan kehendak bawahannya (Safaria, 2004).

perilaku Kepemimpinan sebagai pola mempengaruhi sikap dan perilaku para bawahannya (Wirawan, 2013). Kepemimpinan merupakan norma perilaku yang dipergunakan oleh seorang pemimpin pada saat mencoba mengarahkan dan mempengaruhi perilaku orang lain atau bawahan. "Kepemimpinan adalah sikap, gerakgerik, atau lagak yang dipilih oleh seorang pemimpin dalam menjalankan tugas kepemimpinanya" (Nurkolis, 2006). Kepemimpinan menggambarkan kombinasi yang konsisten dari falsafah, keterampilan, sifat, dan sikap yang mendasari perilaku seseorang pemimpin dalam memimpin bawahannya. Menurut Mulyasa (2007) kepemimpinan merupakan suatu pola perilaku seorang pemimpin yang khas pada saat mempengaruhi anak 
buahnya, pada saat pemimpin mengambil tindakan yang harus dilakukan serta cara pemimpin dalam bertindak dalam mempengaruhi anggota kelompok.

Perilaku, cara, atau strategi yang dilakukan oleh seorang pemimpin ini dilakukan secara konsisten sehingga membentuk kepemimpinan seorang pemimpin. Dari pengertian yang diutarakan oleh para ahli tersebut, maka dapat disimpulkan bahwa pengertian kepemimpinan merupakan cara yang digunakan seorang pemimpin dalam usaha untuk mengarahkan, menggerakkan, dan mempengaruhi perilaku bawahan untuk mencapai tujuan yang ingin dicapaidari sebuah organisasi sekolah. Pemimpin tidak dapat menggunakan kepemimpinan yang sama dalam memimpin bawahannya, namun harus disesuaikan dengan karakter-karakter tingkat kemampuan dalam tugas setiap bawahannya. Kinerja adalah ekpresi potensi berupa perilaku atau cara seorang atau kelompok orang dalam melaksanakan suatu kegiatan atau tugas sehingga menghasilkan sutau produk yang merupakan wujud dari semua tugas dan tanggung jawab pekerjaan yang diberikan kepadanya.

"Kinerja adalah ekspresi potensi berupa perilaku atau cara seorang atau kelompok orang dalam melaksanakan suatu kegiatan atau tugas sehingga menghasilkan suatu produk yang merupakan wujud dari semua tugas dan tanggung jawab pekerjaan yang diberikan kepadanya" (Alisjahbana, 2012). Kinerja guru sangat penting untuk diperhatikan dan dievaluasi karena guru mengemban tugas profesional, artinya tugas-tugasnya hanya dapat dikerjakan dengan kompetensi khusus yang diperoleh melalui program pendidikan. Kinerja guru mempunyai spesifikasi atau kriteria tertentu. Kinerja diukur berdasarkan spesifikasi atau kriteria kompetensi yang harus dimiliki oleh setiap guru. Ada beberapa indikator penilaian kinerja guru yaitu 1) penilaian administrasi pembelajaran, adapun yang dinilai dalam administrasi pembelajaran yaitu, program tahunan, program semesteran, pemetaan standar kompetensi kompetensi dasar, silabus, rencana pelaksanaan pembelajaran, kalender pendidikan, jadwal tatap muka, agenda harian, daftar nilai mata pelajaran dan akhlak mulia, Kriteria Ketuntasan minimal dan absensi siswa, 2) penilaian kegiatan pembelajaran, penilaian ini terdiri dari kegiatan pendahuluan, kegiatan inti pembelajaran dan kegiatan penutup. Kegiatan pendahuluan ini terdiri dari kegiatan menyiapkan peserta didik, melakukan apersepsi, dan memotivasi siswa untuk melibatkan diri dalam kegiatan belajar mengajar, kegiatan inti pembelajaran, yang terdiri dari kegiatan eksplorasi, elaborasi, dan konfirmasi, kegiatan penutup, yang terdiri dari membuat rangkuman simpulan atau pelajaran, melakukan penilaian dan refleksi terhadap kegiatan pembelajaran yang sudah dilaksanakan secara konsisten dan terprogram, memberikan umpan balik terhadap proses dan hasil pembelajaran dikelas, memberikan penugasan terstruktur dan kegiatan mandiri tidak terstruktur, menyampaikan rencana pembelajaran pada pertemuan berikutnya, 3) penilaian evaluasi pembelajaran, adapun yang dinilai dalam penilaian evaluasi pembelajaran yaitu, buku nilai/daftar nilai, melaksanakan tes atau penilaian kognitif, ulangan harian, ulangan tengah semester, ulangan akhir semester, penugasan terstruktur, kegiatan mandiri tidak terstruktur, melaksanakan kegiatan keterampilan atau psikomotor, melaksanakan penilaian afektif ahlak mulia, melaksanakan penilaian afektif kepribadian, analisis ulangan harian, program dan pelaksanaan remedial, program dan pelaksanaan pengayaan, bank soal atau instrument tes.

Kinerja bukan sekedar hasil yang terjadi setelah seseorang melaksanakan pekerjaannya, tetapi termasuk bagaimana proses pekerjaan tersebut dilaksanakan dengan baik (Wibowo, 2012). Menurut Wahyudi (2012) penilaian kinerja ditujukan untuk 
mengetahui seberapa besar mereka bekerja melalui suatu sistem formal dan terstuktur, seperti menilai, mengukur, dan mempengaruhi sifat-sifat yang berkaitan dengan pekerjaan, prilaku, dan hasil, termasuk tingkat ketidakhadiran. Hasil penilaian kinerja ini dapat digunakan untuk mengetahui produktivitas kerja. Menurut Hendry Simanora (1997) kinerja dipengaruhi oleh tiga faktor yaitu individual yang terdiri dari kemampuan dan keahlian, latar belakang dan demografi, faktor psikologis yang terdiri dari persepsi, attitude, personality, pembelajaran dan motivasi. Faktor organisasi yang terdiri dari kepemimpinan, penghargaan, struktur, job design dan sumber daya. Persepsi guru tentang kepemimpinan kepala sekolah dalam memberikan arahan, motivasi, inspirasi, dan keteladanan bagi guru-guru serta staf pegawai ini akan mempengaruhi perilaku guru dalam bekerja. Apabila persepsi guru tentang kepemimpinan sekolah baik maka kinerja guru juga akan baik

\section{METODE}

Penelitian ini termasuk dalam penelitian kausalitas. Penelitian ini dilakukan untuk mendapatkan gambaran mengenai pengaruh persepsi guru tentang kepemimpinan kepala sekolah $(\mathrm{X})$ terhadap kinerja guru $(\mathrm{Y})$. Dalam penelitian ini yang menjadi variabel bebas $(X)$ adalah persepsi guru terhadap kepemimpinan kepala sekolah dan variabel terikat $(Y)$ adalah kinerja guru. Untuk memberikan penjelasan dan penegasan terhadap variabel yang dianalisis agar tidak terjadi salah pengertian, maka variabel dalam penelitian ini dibuatkan definisi varibael penelitian yaitu dimulai dari pengertian persepsi merupakan proses pengolahan informasi dari lingkungan yang berupa stimulus, yang diterima melalui alat indera dan diteruskan ke otak untuk diseleksi, diorganisasikan sehingga menimbulkan penafsiran atau penginterpretasian yang berupa penilaian dari penginderaan atau pengalaman sebelumnya.

Kinerja guru merupakan perilaku guru dalam melaksanakan tugasnya sebagai pendidik dan pengajar ketika mengajar dikelas yang harus sesuai dengan kriteria tertentu dan biasanya terlihat dari situasi dan kondisi kerja sehari-hari. Data dalam penelitian ini yaitu mengenai persepsi guru tentang kepemimpinan kepala sekolah dan kinerja guru dikumpulkan dengan menggunakan instrument kuisioner. Masing-masing variabel penelitian dijabarkan ke dalam indikator-indikator yang akan menjadi pertanyaan kepada responden dalam penelitian ini. Populasi dalam penelitian ini adalah seluruh guru tetap di SMA Laboratorium Undiksha Singaraja yang berjumlah 38 orang. Melihat jumlah populasi dalam penelitian ini yang berjumlah 38 orang makan sampel yang digunakan dalam penelitian ini adalah seluruh populasi. Jenis dan sumber data pada penelitian ini yaitu data jenis data yang digunakan adalah data kuantitatif yang dinyatakan dalam bentuk skala numerik atau angka. Sedangkan sumber data dalam penelitian ini bersumber dari data primer. Metode pengumpulan data yang digunakan dalam penelitian ini adalah studi lapangan yang meliputi penyebaran dokumentasi dan kuisioner. Dokumentasi merupakan teknik pendukung dalam penelitian ini yang digunakan untuk mendapatkan data mengenai keadaan dan jumlah guru di SMA Laboratorium Undiksha Singaraja pada tahun pelajaran 2017. Instrumen kuisisoner sebelum digunakan untuk mengumpulkan data dilapangan terlebih dahulu diuji tingkat validitas dan reliabilitasnya. Untuk menguji tingkat validitas dan reliabilitasnya intrumen penelitian maka kuisioner yang telah dijabarkan maka diujicobakan pada guru-guru SMA N 4 Singaraja sebanyak 30 guru. Pengisian kuisioner ini dilakukan dengan membubuhkan tanda centang pada alternative jawaban yang sudah disediakan kuisioner yang disebarkan menggunakan skala likert dengan lima alternative jawaban. 
Alternatif jawaban pada kuisoner persepsi guru tentang kepemimpinan kepala sekolah terhadap kinerja guru yaitu selalu (SL) diberi 5, sering kali (SK) diberi skor 4, kadang-kadang (KD) kepemimpinan kepala sekolah terhadap kinerja guru adalah dengan analisis deskriptif dan analisis kuantitatif. Analisis kuantitaif yaitu berupa uji $t$ dan analisis deskriptifnya yaitu untuk mejabarkan hasil perhitungan rata-rata skor kinerja guru dan persepsi guru tentang kepemimpinan kepala sekolah di SMA Laboratorium Undiksha Singaraja. Pada analisis kuantitatif dilakukan uji t untuk mengetahui adakah pengaruh persepsi guru tentang kepemimpinan kepala sekolah terhadap kinerja guru di SMA Laboratorium Undiksha Singaraja tahun 2017. Sedangkan pada analisis deskriptif untuk mengetahui kategori persepsi guru tentang kepemimpinan kepala sekolah dan kinerja guru berada diberi skor 3, jarang (JR) diberi skor 2 , dan tidak pernah (TP) diberi skor 1. Dalam penelitian ini metode analisis data yang digunakan untuk mengetahui pengaruh persepsi guru tentang pada kategori sangat baik, baik, cukup baik, kurang baik dan tidak baik.

\section{HASIL DAN PEMBAHASAN Hasil}

Berdasarkan penelitian yang dilakukan pada guru-guru SMA Laboratorium Undiksha Singaraja tahun pelajaran 2017, ditemukan bahwa persepsi guru tentang kepemimpinan kepala sekolah di SMA Laboratorium Undiksha Singaraja termasuk kedalam kategori baik. Hal ini ditunjukkan dengan skor rata-rata persepsi guru tentang kepemimpinan kepala sekolah sebesar 25,777 yang terletak pada nilai konversi 25,32-28,75. Data persepsi guru tentang kepemimpinan kepala sekolah tersebut dapat dilihat dalam Tabel

Tabel 1. Data Persepsi Guru tentang Kepemimpinan Kepala Sekolah

\begin{tabular}{|c|c|c|c|c|c|}
\hline No & \multicolumn{2}{|c|}{ Indikator } & Skor & Rentang skor & Kategori \\
\hline 1 & \multicolumn{2}{|c|}{ Kepala sekolah sebagai pendidik } & 5,483 & $5,480-6,090$ & Sangat baik \\
\hline 2 & \multicolumn{2}{|c|}{ Kepala sekolah sebagai manager } & 1,790 & $1,630-1,830$ & Baik \\
\hline 3 & $\begin{array}{l}\text { Kepala sekolah } \\
\text { administrator }\end{array}$ & sebagai & & $1,630-1,830$ & Sangat Baik \\
\hline 4 & $\begin{array}{l}\text { Kepala sekolah } \\
\text { supervisor }\end{array}$ & sebagai & 5,760 & $5,480-6,090$ & Sangat baik \\
\hline 5 & \multicolumn{2}{|c|}{ Kepala sekolah sebagai pemimpin } & 1,790 & $1,630-1,830$ & Baik \\
\hline $\begin{array}{l}6 \\
7\end{array}$ & \multicolumn{2}{|c|}{$\begin{array}{l}\text { Kepala sekolah sebagai innovator } \\
\text { Kepala sekolah sebagai motivator }\end{array}$} & $\begin{array}{l}3,604 \\
3,646\end{array}$ & $\begin{array}{l}3,230-3,630 \\
3,230-3,630\end{array}$ & $\begin{array}{l}\text { Baik } \\
\text { Baik }\end{array}$ \\
\hline \multicolumn{3}{|c|}{ Total } & 25,777 & $25,32-28,75$ & Baik \\
\hline
\end{tabular}

Hasil perhitungan mengenai kinerja guru di SMA Laboratorium Undiksha Singaraja tahun Pelajaran 2017 termasuk kedalam kategori sangat baik. Hal ini ditunjukkan dengan skor rata-rata kinerja guru sebesar 51,76 yang terletak pada konversi 51,64 57,04 . Secara rinci data kinerja guru dapat dilihat sebagai berikut dalam Tabel 2 .

Tabel 2. Hasil Perhitungan Variabel Kinerja Guru.

\begin{tabular}{|c|c|c|c|c|c|}
\hline No & \multicolumn{2}{|l|}{ Indikator } & Skor & Rentang skor & Kategori \\
\hline 1 & \multirow{2}{*}{\multicolumn{2}{|c|}{$\begin{array}{l}\text { Perencanaan Pembelajaran } \\
\text { Pelaksanaan Pembelajaran }\end{array}$}} & 12,871 & $11,440-14,040$ & Sangat baik \\
\hline 2 & & & 25,669 & $25,090-27,330$ & Sangat baik \\
\hline 3 & $\begin{array}{l}\text { Pelaksanaan } \\
\text { (Evaluasi) }\end{array}$ & Penilaian & 6,212 & $6,280-6,840$ & Sangat baik \\
\hline Tot & & & 51,76 & $51,64-57,04$ & Sangat baik \\
\hline
\end{tabular}


Berdasarkan analisis yang dilakukan dengan menggunakan SPSS 16.0 for windows menunjukkan bahwa tidak terdapat pengaruh persepsi guru tentang kepemimpinan kepala sekolah terhadap kinerja guru. Hasil analisis menunjukkan menunjukkan nilai $t_{\text {hitung }}=1,730<t_{\text {tabel }}=$ 2,028 atau $p$-value $=0,092>\alpha=0,05$. Hal ini berarti $\mathrm{Ha}$ ditolak dan $\mathrm{HO}$ diterima. Dengan demikian persepsi guru tentang kepemimpinan kepala sekolah tidak berpengaruh secara signifikan terhadap kinerja guru di SMA Laboratorium Undiksha Singaraja Tahun Pelajaran 2017. Secara rinci hasil dari analisis yang dilakukan dengan SPSS dapat dilihat pada Tabel 3.

Tabel 3. Hasil Uji t

\begin{tabular}{ccccccc}
\hline Model & $\begin{array}{c}\text { Unstandardized } \\
\text { Coefficients } \\
\text { B }\end{array}$ & $\begin{array}{c}\text { Standardized } \\
\text { Coefficients } \\
\text { Std. Error }\end{array}$ & Beta & t & Sig. \\
\hline 1 & 16.045 & 11.196 & & 1.433 & .160 \\
$\begin{array}{l}\text { Persepsi guru tentang } \\
\text { kepemimpinan kepala } \\
\text { sekolah }\end{array}$ & .290 & .168 & .277 & 1.730 & .092
\end{tabular}

\section{Pembahasan}

Berdasarkan hasil penelitian yang diperoleh, dapat diketahui bahwa persepsi guru tentang gaya kepemimpnan kepala sekolah di SMA Laboratorium Undiksha Singaraja tahun pelajaran 2017 termasuk dalam kategori baik karena berada pada konversi 25,32-28,75 dengan skor rata-rata 25,77 . Hal ini berarti persepsi guru tentang kepemimpinan kepala sekolah di sekolah ini sepenuhnya baik. Oleh karena itu kepala sekolah diharapkan tetap menjaga dan terus meningkatkan kemampuan kepemimpinannya serta mampu mengayomi bawahannya. Sehingga melalui persepsi yang baik terhadap kepala sekolahnya guru cenderung akan melakukan kinerjanya dengan baik pula. Sejalan dengan pendapat yang dikemukakan oleh Wahyudi (2009) bahwa terciptanya kualitas kinerja guru yang professional di sekolah membutuhkan dukungan peran kepala sekolah yang kompeten sebagai leader dan manager.

Sedangkan untuk skor rata-rata kinerja guru di SMA Laboratorium Undiksha Singaraja tahun pelajaran 2017 di ketahui sebesar 51,76 skor ini masuk ke dalam kategori sangat baik karena berada pada konversi 51,64-57,04 tergolong dalam kategori sangat baik. Hal ini menunjukkan bahwa kinerja guru di sekolah ini sudah sangat baik, guru sudah menjalankan tugasnya sebagai pendidik dan memiliki semangat yang tinggi dalam melakukan kinerjanya. Jika guru tidak melaksanakan suatu sistem kerja yang kondusif akan mengakibatkan banyak guru yang kehilangan semangat kerja di dalam menjalankan tugasnya. Menurunnya semangat inilah yang merupakan masalah yang harus dihindari. Oleh sebab itu, tugas mendidik dari seorang guru ini pada dasarnya hanya dapat di laksanakan oleh guru yang memiliki kinerja yang tinggi. Hal ini dapat dilihat pada masing-masing indikator kinerja guru yaitu perencanaan, pelaksanaan, dan penilaian atau evaluasi berada pada kategori sangat baik. Oleh karena itu guru-guru perlu mempertahankan kinerjanya karena kinerja guru yang baik akan meningkatkan hasil belajar siswa.

Berdasarkan hasil penelitian yang diperoleh tidak dapat dibuktikan bahwa adanya pengaruh yang signifikan antara persepsi guru tentang kepemimpinan kepala sekolah terhadap kinerja guru di SMA Laboratorium Undiksha Singaraja Tahun Pelajaran 2017. Hasil analisis pada Tabel 4.3 menunjukan nilai $t_{\text {hitung }}=1,730<$ $t_{\text {tabel }}=2,028$ atau $p$-value $=0,092>\alpha=$ 0,05 . Hal ini berarti $\mathrm{Ha}$ ditolak dan $\mathrm{HO}$ diterima. Dengan demikian persepsi guru 
tentang kepemimpinan kepala sekolah tidak berpengaruh secara signifikan terhadap kinerja guru di SMA Laboratorium Undiksha Singaraja tahun pelajaran 2017. Hasil ini tidak membuktikan relevasi teori menurut Hendry Simanora,1997 bahwa terdapat tiga faktor yang mempengaruhi kinerja guru diantaranya faktor individual, faktor psikologis dan faktor organisasi. Pada faktor psikologis ini terdapat persepsi, attitude, personality, pembelajaran dan motivasi sedangkan pada faktor organisasi ini terdapat kepemimpinan, penghargaan, struktur, job design, sumber daya. Selain itu temuan dari penelitian yang dilakukan oleh Made Krisna Andi Putra dengan judul penelitian pengaruh persepsi guru tentang gaya kepemimpinankepala sekolah dan iklim kerja terhadap kinerja guru di SMK 1 Gianyar menunjukkan hasil bahwa terdapat pengaruh yang signifikan kepemimpinan kepala sekolah terhadap kinerja guru dan iklim kerja.

Hal ini berarti untuk di SMA Laboratorium Undiksha Singaraja tahun 2017 persepsi guru tentang kepemimpinan kepala sekolah terhadap kinerja guru tidak memiliki pengaruh yang signifikan, kemungkinan dikarenakan guru-guru disekolah ini sudah mandiri dan mampu menyelesaikan kualifikasi akademiknya dengan sangat baik dan memenuhi syarat, selain itu kinerja guru di sekolah ini sudah profesional yaitu memenuhi keempat kompetensi akademik yang teridiri atas kompetensi pedagogik, kompetensi kepribadian, kompetensi sosial, kompetensi professional.

\section{SIMPULAN DAN SARAN Simpulan}

Persepsi guru tentang kepemimpinan kepala sekolah di SMA Laboratorium Undiksha Singaraja tahun ajaran 2017 tergolong dalam kategori baik. Hal ini dapat di lihat dari skor rata-rata keseluruhan persepsi guru tentang kepemimpinan kepala sekolah sebesar 25,77. Kinerja guru di SMA Laboratorium Undiksha Singaraja tahun pelajaran 2017 tergolong dalam kategori sangat baik. Hal ini dapat dilihat dari skor rata-rata keseluruhan kinerja guru 51,76. Persepsi guru tentang kepemimpinan kepala sekolah tidak berpengaruh secara signifikan terhadap kinerjaa guru di SMA Laboratorium Undiksha Singaraja tahun ajaran 2017 ditunjukkan dengan nilai $t_{\text {hitung }}=$ $1,730<t_{\text {tabel }}=2,028$ atau $p$-value $=0,092>$ $\alpha=0,05$. Karena $t_{\text {hitung }}$ kurang dari $t_{\text {tabel }}$ hal ini berarti $\mathrm{Ha}$ ditolak dan $\mathrm{HO}$ diterima. Dengan demikian persepsi guru tentang kepemimpinan kepala sekolah tidak berpengaruh secara signifikan terhadap kinerja guru di SMA Laboratorium Undiksha Singaraja Tahun Pelajaran 2017.

\section{Saran}

Berdasarkan hasil penelitian dan simpulan, maka dapat diajukan beberapa saran yaitu Bagi pihak sekolah dalam upaya meningkatkan kinerja guru, kepala sekolah hendaknya dapat memberikan arahan dan mengatur peran-peran yang harus dilakukan guru, melakukan pengawasan terhadap kinerja guru, mendengar saran dan pendapat guru, memberikan motivasi, melakukan interaksi dan melibatkan peran guru sehingga guru dapat meningkatkan kinerjanya dengan lebih baik lagi. Sedangkan bagi semua guru diharapkan mempertahankan kinerja yang sudah dilakukan selama ini. Bagi mahasiswa lain yang berminat meneliti pengaruh persepsi guru tentang kepemimpinan kepala sekolah agar mengembangkan penelitian ini

lebih lanjut dan pempertimbangkan variabel lain yang belum di uji dipenelitian ini.

\section{DAFTAR PUSTAKA}

Alisjahbana. 2012. Manajemen Kinerja Pemerintah Daerah.

Yogyakarta:Laksbang

Pressindo.

Hendry, Simanora. 1997. Manajemen Sumber Daya Manusia. Yogyakarta: STIE YKPN.

Luthans, Fred. 2006. Perilaku Organisasi. Yogyakarta: Andi. Mulyasa. 2007. Manajemen Berbasis Sekolah. Bandung: PT Remaja Rosdakarya. 
Nurkolis. 2006. Manajemen Berbasis Sekolah. Jakarta: Grasindo.

Permata. 2012. Pengaruh Pengendalian Internal dan Kepemimpinan terhadap Kinerja Karyawan SPBU Yogyakarta. Tersedia pada http://nominal/article/download/993/79

6 (diakses tanggal 3 Juli 2013). Safaria, Triantono. 2004. Kepemimpinan. Yogyakarta: Graha Ilmu.

Sedarmayanti. 2001. Sumber Daya Manusia dan produktivitas Kerja Bandung: Mandar Maju.

Undang-undang Republik Indonesia No. 20 Tahun 2003 tentang Sistem Pendidikan Nasional.

Wahdjosumidjo. $2010 . \quad K e p e m i m p i n a n$ Kepala Sekolah Tinjauan Teoritik dan Permasalahannya. Cetakan ke-7. Jakarta: Rajawali Press.

Wahyudi. 2009. Kepemimpinan kepala sekolah dalam organisasi pembelajaran. Bandung: Alfa Beta.

Wahyudi. $2012 . \quad$ Pengembangan Pendidikan. Jakarta: PT Prestasi Pustakaraya.

Walgito. 2004. Pengantar Psikologi Umum. Yogyakarta: Andi.

Wibowo. 2012. Manajemen Kinerja. Jakarta: Rajawali Pers.

Wirawan. 2013. Kepemimpinan Teori, Psikologi, Perilaku Organisasi, Aplikasidan Penelitian. Jakarta: PT Raja Grafindo Persada. 